3. Lord G.M., Matarese GI., Howard J.K. et al. Leptin modulates the T-cell immune response and reverses starvation-induced immunosuppression. Nature. - 2018. - Vol. 394. - P. 897-901.

4. Houde A.A. Leptin and adiponectin DNA methylation levels in adipose tissues and blood cells are associated with BMI, waist girth and LDL-cholesterol levels in severely obese men and women. BMC Med. Genet. - 2015. - Vol. 16. - P. 29.

DOI https://doi.org/10.30525/978-9934-26-038-4-45

\title{
ВИЯВЛЕННЯ СТУПЕНЯ АДАПТАЦІЇ ІМУННОЇ СИСТЕМИ ДО ФІЗИЧНИХ НАВАНТАЖЕНЬ
}

\author{
Луковська О. Л. \\ кандидат медичних наук, \\ професор кафедри фізіології та спортивної медицини \\ Придніпровська державна академія фізичної культури і спорту \\ Кудрявцева В. С. \\ кандидат біологічних наук, \\ дочент кафедри фізіології та спортивної медицини \\ Придніпровська державна академія фізичної культури і спорту \\ Бурдаєв К. В. \\ старший викладач кафедри фізіології та спортивної медицини \\ Придніпровська державна академія фізичної культури і спорту

\section{Петречук Л. М.} \\ кандидат медичних наук, \\ дочзент кафедри фізіології та спортивної медицини \\ Придніпровська державна академія фізичної культури і спорту

\section{Мізін В. В.} \\ викладач кафедри фізіології та спортивної медицини \\ Придніпровська державна академія фізичної культури і спорту \\ м. Дніпро, Україна
}

Надмірні тренувальні навантаження пригнічують нормальну функцію імунної системи, підвищуючи сприйнятливість перетренованого організму спортсмена до інфекційних захворювань. Результати числен- 
них досліджень показують, що короткочасні періоди інтенсивних навантажень на деякий час порушують реактивність імунної системи, а проведення виснажливого тренування в наступні дні веде до їі пригнічення [4]. Деякі вчені наводили випадки виникнення захворювань після одноразових виснажливих навантажень. Подібне пригнічення функції імунної системи характеризується аномально низькими рівнями як лімфоцитів, так і антитіл. Саме при таких низьких рівнях мікроорганізми, потрапляючи в організм спортсмена, не пригнічуються і викликають виникнення захворювань [3]. Таким чином, виконання інтенсивного фізичного навантаження при захворюванні ще більше знижує здатність організму чинити опір, що підвищує ризик виникнення серйозних ускладнень. Сучасне суспільство характеризується наявністю професійних колективів, що працюють в екстремальних умовах (освоєння космосу і світового океану, будівництва у важкодоступних кліматичних зонах і ін.). Результати досліджень, проведених серед космонавтів, будівельників в особливих умовах, осіб, що займаються освоєнням Арктики і Антарктиди, свідчать про зниження природної резистентності організму при екстремальних умовах праці [2]. Ця проблема має декілька важливих аспектів теоретичного і практичного характеру. Центральне питання може бути сформульовано наступним чином: чому в період підвищених вимог до організму розвивається вторинний імунодефіцит, в чому біологічне значення «несправності» імунітету? У цей період слід було б очікувати підвищення імунологічної реактивності. Багато трудових та спортивних колективів відчувають тривалий фізичний та стресорний вплив. Однак між трудовими і спортивними навантаженнями є ряд суттєвих відмінностей. На відміну від трудової діяльності, навіть в екстремальних ситуаціях, навантаження в спорті за останні 20 років зросли в 4-5 раз при яскраво вираженому омолодженню практично всіх видів спорту. Друга відмінність - виражений психоемоційний компонент, який значно перевершує такий у професійній діяльності. 3 питання про вплив спортивних навантажень на імунітет не має єдиної точки зору. Результати попередніх досліджень свідчать, що заняття фізкультурою i спортом надавали сприятливий вплив, сприяли зниженню захворюваності, збільшенню тривалості життя, поліпшенню показників природного імунітету. Однак у роботах, проведених в 80-х роках, було показано, що сучасний спорт вищих досягнень може надавати пригнічувану дію на систему імунітету [1]. Проведені дослідження в цілому свідчать про залежність показників імунологічної реактивності організму від обсягу та інтенсивності навантажень. При помірному обсязі фізичних навантажень підвищуються показники імунітету. Чим більше інтенсивність фізичних вправ, тим нижче може бути імунологічна реактивність організму. Разом 3 тим мінімальні за енерготратами фізичні навантаження залишають стабільними показники імунітету і сприяють стимулюючому впливу на імунну систему. 
Виявлено, що вже при одноразовому м'язовому навантаженні спостерігались певні зміни низки імунологічних показників. Було встановлено, що тренувальні навантаження підготовчого періоду викликали незначні коливання імунологічних показників, причому в разі деякого зниження їх останні поверталися до вихідних значень відразу після дня відпочинку або зменшення навантаження. У змагальному періоді підготовки імунний статус спортсменів значно змінювався. Найбільш істотні зміни імунологічних показників були отримані при дослідженні місцевого та загального імунітету у спортсменів протягом місячного тренувального циклу, що включав змагання, тобто періоду безпосередньої підготовки до відповідальних стартів сезону. Було встановлено, що граничні по інтенсивності та обсягу тренувальні навантаження приводили до різкого зниження рівнів нормальних антитіл, імуноглобулінів A, M, G класів, секреторного імуноглобуліну A, лізоциму і загального білка, тобто досить важливих елементів імунної системи, що забезпечують захист від захворювань. Зниження цих показників є ще більш вираженим після участі у відповідальних змаганнях. При аналізі індивідуальних імунологічних показників встановлено явище повного зникнення 3 крові біологічних секретів нормальних антитіл та імуноглобулінів, яке настає протягом 1-2 годин з моменту впливу на людину гранично переносимих фізичних $\mathrm{i}$ психоемоційних навантажень, тобто фактично наступає функціональний параліч імунної системи і вона різко знижує свої функції по захисту організму від захворювань. У $13,5 \%$ обстежених осіб не вдавалося тестувати нормальні антитіла в період відповідальних змагань, в той час як в перехідному періоді підготовки вони визначалися в досить високих титрах (1/128-1/256). У змагальному періоді у певної частини спортсменів зникали і імуноглобуліни різних класів (А - у 7,9\%, секреторний $\mathrm{A}-$ у $5,1 \%, \mathrm{G}-\mathrm{y}$ $6,5 \%$ ). Все це дозволило виявити загальну тенденцію адаптації імунної системи людини до фізичних навантажень. Певна динаміка змін імунологічного статусу спортсменів в залежності від фізичних навантажень стала підставою для виділення принаймні чотирьох фаз адаптації.

1. Фаза мобілізації спостерігається, коли тренувальні навантаження мають інтенсивність по пульсового режиму не більше 160 уд/хв і переважає так звана аеробна продуктивність. Імунологічні резерви організму мобілізуються в цей період. Кількість гострих респіраторних захворювань зменшується до мінімуму, значно поліпшуються загальне самопочуття і працездатність.

2. Фаза компенсації наголошується в період збільшення інтенсивності навантажень 3 пульсом вище 160 уд/хв (до 170) при тижневому обсязі такої роботи до 12 год. Основні ефекти полягають у компенсаторному підвищенні одних імунологічних показників при порушенні інших. Фізіологічний захист організму залишається практично на тому ж рівні, що і в попередній фазі, мабуть, із-за мобілізації резервів імуноло- 
гічних механізмів. Захворюваність достовірно не відрізняється від такої в попередній фазі.

3. Фаза декомпенсації спостерігається в період високих навантажень \% від максимуму з великими обсягами (8-10 год на тиждень) у змагальному періоді, при яких пульс буває вище 170 уд/хв. Її основні відмінності - у різкому зниженні всіх показників імунітету. Фізіологічні резерви імунної системи перебувають на межі виснаження. Захворюваність у цій фазі досягає свого піку. Організм знаходиться в стані імунологічного ризику, тобто виникає вторинний імунодефіцит.

4. Фаза відновлення спостерігається в післязмагальний період, після значного зниження фізичних навантажень, а також у початковому періоди наступних тренувальних циклів. Показники імунологічного і гормонального статусу поступово повертаються (або майже повертаються до початкових рівнів попереднього циклу.

Таким чином, вплив тривалості і інтенсивності фізичних навантажень на імунологічну реактивність спортсменів свідчить про фазність змін в стані захисних реакцій. Аналіз взаємозв'язку імунологічних показників на різних фазах адаптації до м'язових навантажень дозволяє припустити існування авторегуляції захисних властивостей організму, причому компенсаторне збільшення одних показників при падінні інших до певного моменту виявляється досить ефективним. Резервні можливості імунної системи у перші дві фази ще дають ефективний захист організму від інфекцій - у фазах «мобілізації» і «компенсації». Перехід у третю фазу - «декомпенсації» - обумовлений наростанням м'язово емоційного стресу, характерного для сучасної системи спортивного тренування. При цьому пригнічення імунологічних показників корелює із зростанням захворюваності. Режими навантажень, при яких настає фаза виснаження резервних можливостей імунної системи, індивідуальні для кожного спортсмена, залежать від багатьох факторів, в тому числі і його генотипу. Ця обставина робить безперечною необхідність імунологічного контролю за спортсменами високих кваліфікацій. Питанням першорядної важливості - необхідність вивчення механізмів зниження імунітету у людини при стресорних фізичних навантаженнях.

Таким чином, виявлення ступеня адаптації імунної систем на фізичні навантаження спортсменів дозволяє оцінити ефективність тренувального процесу, а також своєчасно запобігти розвитку захворювань, пов’язаних $з$ професійною діяльністю спортсменів.

\section{Література:}

1. Назар П.С. Медико-біологічні основи фізичної активності і спорту. Київ. 2012. 462 с

2. Губина А.Е. Сезонные изменения показателей эндокринной и иммунной систем спортсменов в природно-климатических условиях Среднего Приобья: диссертация ... кандидата Медицинских наук. 2018. $103 \mathrm{c}$. 
3. Liu D., Wang R., Grant A.R. Immune adaptation to chronic intense exercise training: new microarray evidence. BMC Genomics. 2017. Vol. 18(1). P. 29.

4. Bouaziz T., Makni E., Passelergue P. Multifactorial monitoring of training load in elite rugby seven players: cortisol/cortisone ratio as a valid tool of training load monitoring. Biol Sport. 2016. Vol. 33 (3). P. 231-239.

DOI https://doi.org/10.30525/978-9934-26-038-4-46

\title{
ПРОТИВОСУДОРОЖНАЯ И СЕДАТИВНАЯ АКТИВНОСТЬ ПРОИЗВОДНЫХ БЕНЗДИАЗЕПИНОВ И ИХ ВЛИЯНИЕ НА МИКРОФЛОРУ КИШЕЧНИКА
}

\author{
Онуфиенко О. В. \\ кандидат биологических наук, \\ доиент кафедры физиологии \\ Одесский национальный медицинский университет \\ Русакова М. Ю. \\ кандидат биологических наук, \\ доиент кафедры физиологии \\ Одесский национальный медицинский университет
}

Кащенко О. А.

кандидат медииинских наук,

доиент кафедры физиологии

Одесский национальный медицинский университет

Волохова Г. А.

кандидат медицинских наук,

доиент кафедры физиологии

Одесский национальный медицинский университет

\section{Прищепа Е. А.}

ассистент кафедры физиологии

Одесский национальный медицинский университет

2. Одесса, Украина

Наиболее широко в медицинской практике используют нейротропные средства из группы производных бенздиазепина. Эти вещества 